\title{
METHODS OF FINANCIAL CONTROL OF THE STATE FINANCIAL INSPECTION OF UKRAINE
}

\author{
Anatolii Shulha', Iryna Zharovska²
}

\begin{abstract}
The aim of the article is to determine the methods of financial control of the State Financial Inspection of Ukraine. The subject of the study is the methods of financial control of the State Financial Inspection of Ukraine. Methodology. The study is based on the use of general scientific and special-scientific methods and techniques of scientific knowledge. The logic-semantic method was used to determine the content of the notions of "method", "form", and "concept". The comparative legal method enabled to compare doctrinal approaches to this issue. The normative-dogmatic method enabled to interpret the content of legal regulations of the domestic legislation on the issue of determination of financial control methods of the State Financial Inspection of Ukraine. The systemstructural method enabled to analyse the most common methods of financial control. Methods of analysis and synthesis helped study certain methods of financial control to formulate further conclusions regarding the most optimal functioning of the State Financial Inspection of Ukraine. Practical implications. The determination of the methods of financial control of the State Financial Inspection of Ukraine enabled to make recommendations for improving the procedure of financial control of the State Financial Inspection of Ukraine, as well as identify problematic issues that require further consideration and research. Relevance/originality. The methods of financial control are defined and classified. The absence of a check without linkage to the subject (public procurements) among the forms of control of the SFI of Ukraine is revealed so that independent coexistence of such a form of control as "public procurement check," which methods are documentary and/or factual examination, can be asserted.
\end{abstract}

Key words: control, method, financial control, State Financial Inspection, check, scanning.

JEL Classification: P43, M42

\section{Introduction}

Control is an eclectic phenomenon, widely used, therefore, it may be characterized differently, for example, considering it as one of the main principles of management, as a stage of management process (cycle), the method of management as a mode of activity and the possibility of influencing on the behaviour of the relevant object, a function of public administration, an integral part of adoption and implementation of managerial decisions, which is continuously involved in this process from its beginning to its completion (Kocherin, 1982). For today, the system of state financial control in Ukraine is at the stage of formation and development. From the aim of state financial control up to certain powers of officials implementing the control bodies' competence, all components of the system are reformed on the basis of changes in the legal regulation of individual control issues. At the same time, one of the problematic issues is the definition of methods of financial control, in particular, used by the State Financial Inspection of Ukraine.

Corresponding author:

${ }^{1}$ Kharkiv National University of Internal Affairs, Ukraine.

${ }^{2}$ Lviv Polytechnic National University, Ukraine.
Some of the problematic aspects of the activities of the State Financial Inspection of Ukraine were considered in scientific works of: V. B. Averianov, O. F. Andriiko, H. V. Atamanchuk, A. M. Bandurka, D. N. Bakhrakh, L. P. Bila, Yu. P. Bytiak, V. M. Harashchuk, O. V.Zaichuk, S. V. Kivalov, Z. R. Kisil, R. V. Kisil, V. V. Kopeichykov, A. M. Kolodii, V. K. Kolpakov, Yu. M. Kozlov, O. M. Kurakin, A. F. Melnyk, V. V. Novikov, O. P. Orliuk, O. A. Pavliukh, O. F. Skakun, Yu. M. Starilov and many others. However, in the legal literature, a considerable number of interrogations does not involve a comprehensive study of the issue of financial control methods of the State Financial Inspection of Ukraine. Therefore, the aim of the article is to determine and consider the methods of financial control of the State Financial Inspection of Ukraine.

\section{Presentation of the main material}

The method is usually considered as the technique or means to achieve the goal and objectives (Osnovin, 1971). The method is a set of practices or operations of practical and theoretical development of reality 
(Prokhorova, 1998). Therefore, the methods of control are a set of ways and techniques of its implementation, according to V. M. Oparin (Oparin, 2002). While strongly supporting the scholar regarding the interpretation of control methods, the means as an integral part of the methods should be clarified. Indeed, without the means of electronic computer technology, means of measurement, weighing, audiovisual, electronic, and other technical means, means of communication, etc., not a single control procedure can be carried out. For example, the control measurement is carried out with the obligatory use of means enabling to rate and weight the monitored parameters. Alternatively, when exercising control over the accounting of payroll, the controller usually uses a calculator or other means of electronic computing for the speed and accuracy of the results obtained. Therefore, it would be considered more accurate to define methods of control as techniques, ways, and means to determine compliance of controlled objects with given parameters.

The above definition of the method of control reveals that it is impossible to agree in general with L. M. Kapaieva and M. S. Liakh that the methods of financial control are ways, techniques of its implementation that make observations (general review of the state of the object's financial activity), check (carried out on-site using balance, reporting, expense documents), examination (carried out on individual aspects of financial activity and based on a wide range of indicators), analysis (conducted on the basis of current or annual reporting and is characterized by the use of analytical techniques), revision (method of documentary control of an enterprise, institution, organization, compliance with financial legislation, technique of documentary detection of financial abuses) (Kapaieva, Liakh, 2004). Similarly, L. K. Voronov's perspective cannot be supported, because the main methods of financial control are observation, examination, accounting, analysis, check and revision (Voronova, 2009). The determination of methods of financial control, such as revision; check; inspection; examination; observation; analysis; listening, as the most frequently used is analogically inaccurate (Nahrebelnyi, Chernadchuk, Sukhonos, 2003).

Therefore, the absence of a legislative definition of the criteria enabling to delimitate and interpret concepts of the form and method of control leads to the inconsistency in the interpretation of their content. However, it is indisputable that concepts are an important component of theory and practice that comprise the scientific knowledge about the nature and essence of the phenomenon, and reflect the characteristic patterns and connections. A concept is a form of scientific thinking, a form of knowledge of reality as it is. (Kolesnyk, 2014). The system of concepts reveals the content of the theory. Without clear, scientifically substantiated concepts, there can be no scientific theory. In this system, categories are wide-ranging fundamental concepts that concentrate knowledge about the most important aspects and characteristics of the object under the study, its regular connections and relations (Kolesnyk, 2014). Once more this proves that the Law of Ukraine "On the Basic Principles of the Implementation of the State Financial Control in Ukraine" No. 2939-XII as of January 26, 1993, should provide for the legislative definition of the concepts, which are relevant for the implementation of corresponding activities, including the concept of forms of control and its methods.

Nowadays, a number of authors understand the forms of control as the ways of expressing its content (Nahrebelnyi, Chernadchuk, Sukhonos, 2003). The authors of this article argue that methods, not the forms, characterize the techniques, ways, and means of conducting control actions by the subject. Moreover, for the legal regulation of state financial control by the SFI bodies of Ukraine, this argument is reflected in the legislation. Therefore, observation, examination, and analysis should be included in the list of methods of control.

The revision and check of public procurement are the forms of control of the SFI of Ukraine, according to provisions of the Regulation on the SFI of Ukraine, the Law of Ukraine "On the Basic Principles of the Implementation of the State Financial Control in Ukraine" No. 2939-XII as of January 26, 1993. Thus, the revision should not be among the methods of financial control, as the legislation clearly defines it as the form of control of SFI of Ukraine.

Considering the check, in particular, the public procurement check, this construction clearly defines the form of control of the SFI of Ukraine, regulated according to the Law of Ukraine "On the Basic Principles of the Implementation of the State Financial Control in Ukraine" No. 2939-XII as of January 26, 1993, the Regulation on the SFI of Ukraine, the Procedure for carrying out inspections of public procurement by the State Financial Inspection and its local bodies, approved by the Resolution of the Cabinet of Ministers of Ukraine No. 631 as of August 1,2013, and other legal regulations of the legislation of Ukraine.

The analysis of these regulations shows that a form of control such as a check without linkage to the subject (public procurements) is not defined among the forms of control of the SFI of Ukraine. Therefore, considering the check as such, this category can be understood as the method of control. The above is proved by clause 16 of the Procedure for carrying out public procurement inspections of the SFI of Ukraine No. 631: "During the public procurement check, a documentary and/or factual examination of the issues of the program for the public procurement check is conducted." However, considering the use of the same term for the form and method of control, it is necessary to be accurate using 
the term "check" when identifying the methods and forms of the SFI of Ukraine. In other words, it should be clarified whether the form or method is meant.

To eliminate this problem, it is possible to change the terminology of financial control to use different terms for the form and method of control. For example, O. B. Morhulets suggests a successful classification of methods. Accordingly, the methods of control are classified into the following groups: factual (laboratory analysis, control acquisition, control measurement of completed building, assembling, repair works, time and motion study, inventory, examination, control (trial) provision of a new service in quality and quantity, normative check, experiment, etc.); calculating and analytical (technical and economic calculations, analytical estimation, arithmetic checking, dynamicalstatistical estimation); documentary (study of the essence and content of the documents reflected in operations, logical check, accounting correspondence check, counter-verification of documents, etc.) (Morhulets, 2012).

This classification is consistent with the objective to implement the functions of financial control by the use of specific methods of financial control, which reflect the principles of a general approach to the object of control. These principles are based on a combination of general scientific and methodological techniques of knowledge, which enables to interrogate the legality, reliability, feasibility, and economic efficiency of financial transactions and processes based on the use of accounting, reporting, regulatory and other information in combination with the examination of the actual state of affairs of the object of control (Nahrebelnyi, Chernadchuk, Sukhonos, 2003).

Concerning the specific methods of state control carried out by SFI of Ukraine, their list is very diverse. For example, A. F. Andriiko argues that the function of control in public administration consists in analysing and comparing the actual state of affairs in one or another sphere with what is required of them, the deviations in the task performance and the causes of these deviations, as well as the activity assessment and the expediency of this way (Averianova, 2003). While fully supporting the scientist in relation to the distinguished methods of state control, the restriction of the content of this phenomenon is arguable. To be precise, the list of methods that can be used by the controller is broader and encompasses such methods as observation, analysis of the activities of the relevant authorities and their officials concerning the tasks assigned to them, compliance with the rules, norms, and standards established by the state (Voronova, 2006); listening, contrast, comparing and other general and special techniques, ways and means of achieving the purpose of the control activity.

The list of methods of financial control is not clearly defined within the framework of a separate article of the law or regulation, but a significant amount of such methods is defined in the content of the act. For example, Article 3 of the Law of Ukraine "On the Basic Principles of the Implementation of the State Financial Control in Ukraine" No. 2939-XII as of January 26, 1993, provides for that "Public financial audit shall be a type of the public financial control and shall consist in examination and analysis of the actual state of affairs..." From this definition, the following methods of the public audit are identified as examination and analysis. Article 4 of the same law provides for that "inspection shall be carried out by the body of state financial control in a form of revision and shall consist in documentary and factual examination..." Therefore, the types of examination, such as factual and documentary, are selected.

Therefore, the most widely used methods of financial control of the SFI of Ukraine should be considered. Inventory, survey, and control measurement of material assets, works, and services are all classified to the methods of factual examination. When they are used, the object of control provides access to warehouses, storage facilities, production facilities, and other premises owned or used by the object of control. In addition, the officials of the controlling body have the right to demand from the head of the object under control or his deputy to create the appropriate conditions for carrying out the factual examination with the participation of materially responsible persons of the object under control and, in the case of verification of the scope of work performed, representatives of the business entity, that is, a performer (clause 18 of the Procedure for carrying out public procurement inspections of the SFI of Ukraine No. 631 (The Cabinet of Ministers of Ukraine)).

During the factual examination, specific methods may be an opinion poll and questionnaire survey. In the course of the inspection, in case of some negative results, the control body makes a decision on conducting a check or revision (Voronova, 2006). In contrast to the factual examination as a method of control, a documentary examination is carried out using methods of financial state diagnosis, reporting examination, primary analysis of compliance with financial legislation, assessing the compliance of activities with statutory documents (Voronova, 2009). Therefore, the documentary examination involves control by examining documents of the object of control. To date, some of them are stored and processed on electronic media. Therefore, in case of document circulation with the use of electronic storage and processing of information, the law provides for that, upon the request of an official of the controlling body, the head of the object under control shall ensure provision of corresponding documents in hard copy and in the required number of copies, as well as unimpeded access to electronic documents (clause 17 of the Procedure for carrying out public procurement inspections of the SFI of Ukraine No. 631 (The Cabinet of Ministers of Ukraine)). A mechanical precision check is a type 
of documentary examination that involves checking again calculations and transmission of information (Nemchenko, Redko, 2012).

Observation (monitoring) is the general monitoring of the financial activity of the entity under control (Nahrebelnyi, Chernadchuk, Sukhonos, 2003). Scanning is a continuous, elemental review of information (for example, a review of primary documents on cash flow in the cash register in order to establish an unusual fact) (Nemchenko, Redko, 2012). Accounting is a very specific financial-control method, which is used only by the control bodies in the registration of entities (for example, taxpayers) or in other cases, determined by the current legislation. Accounting is not limited to registration work, but also provides for analytics and the creation of an information base (Voronova, 2009).

The analysis is carried out according to the reporting data (current or for a certain period), using such special statistical methods as an index, a method of average and relative values. The main financial and economic characteristics of the object under control are analysed to identify implicit violations of financial discipline and their causes. In this case, a financial-economic method of comparison is especially effective (Voronova, 2006). Analytical tests are methods of comparison, both in absolute units and in relative ones (indexes, coefficients, percentages) (Nemchenko, Redko, 2012). Hearing of reports, information of officials on financial activities at meetings of some state executive bodies or their joint meetings with representatives of the public, other elements of the mechanism of the state in the form of conferences, round tables, etc., is a separate control method (Nahrebelnyi, Chernadchuk, Sukhonos, 2003).

Confirmation involves a written response from the client or third parties in order to confirm the accuracy of information (for example, confirmation of receivables) of income (Nemchenko, Redko, 2012). Confirmation as a control method of the SFI of Ukraine may be a kind of "counter" verification, that is, the primary documents or reporting data are compared with similar or interrelated data of the counterparty (Voronova, 2006). The factual examination should be understood as the quantitative and qualitative status check of the objects by examination, review, measurement, recalculation, weighing, laboratory analysis, and other methods for checking the actual state of assets.

The documentary examination is a check of documents and records, which can be technical, arithmetic, and substantive. The technical examination consists of visual checking of the correctness of all requisite records, the identification of groundless corrections, erasures, adscript in text and figures, and the authenticity check of signatures of officials and materially responsible persons. An arithmetic check of documents is the check of calculation correctness in documents, account registers, and reporting forms. A substantive check of documents enables to verify the legality and feasibility of economic transactions, the correctness of transactions on accounts and inclusion in the items of expenditure and gross revenue (Nemchenko, Redko, 2012).

\section{Conclusion}

Therefore, it should be noted that the methods of financial control of the SFI of Ukraine represent a set of techniques, ways, and means that allow the bodies of the system to achieve their goals. The choice of control methods depends primarily on the scope of work and tasks. For this purpose, the main criteria are the minimization of duty hours for control works and the effectiveness of the chosen method of control. In addition, the methods of financial control should be chosen depending on a combination of factors: the subject of control, the object of control, the aim and objectives facing the subject of control and the grounds for control legal relations, as well as on other circumstances.

\section{References:}

Kocherin, E. A. (1982). Kontrol kak funktsiia upravleniia [Control as a function of management]. M.: Znanie. (in Russian)

Osnovin, V. S. (1971). Osnovy nauki sotsialnogo upravleniia [Fundamentals of social management]. Voronezh: Voronezh University Press. (in Russian)

Prokhorova, A. M. (Ed.). (1998). Bolshoi entsiklopedicheskii slovar [Great encyclopedic dictionary] (2nd ed.). M.: Great Russian Encyclopedia. St. Petersburg: Norint. (in Russian)

Oparin, V. M. (2002). Finansy (zahalna teoriia): navch. posibnyk dlia stud. ekon. spets. vyshchykh zakladiv osvity [Finance (General theory): a teaching manual for students of economic special higher education institutions] (2nd ed.). K.: KNEU. (in Ukrainian)

Kapaieva, L. M., Liakh, M. S. (2004). Finansove pravo: navchalnyi posibnyk [Financial law: a teaching manual]. Kyiv: Center for Educational Literature. (in Ukrainian)

Voronova, L. K. (Ed.). (2009). Finansove pravo Ukrayiny: navchalnyi posibnyk [Financial law of Ukraine: a teaching manual]. K.: Legal unity. (in Ukrainian)

Nahrebelnyi, V. P., Chernadchuk, V. D., Sukhonos, V. V. (2003). Finansove pravo Ukrainy. Zahalna chastyna: navchalnyy posibnyk [Financial law of Ukraine. General part: a teaching manual]. Sumy. (in Ukrainian)

Kolesnyk, M. O. (2014). Poniattia «systema» i «mekhanizm» shchodo protydii zlochynnosti nepovnolitnikh: problemy spivvidnoshennia [Concept of "system" and "mechanism" for counteracting juvenile delinquency: 
correlation problem]. Naukovyi visnyk Uzhhorodskoho natsionalnoho universytetu. Seriia Pravo, 25, 203-206. (in Ukrainian)

The Cabinet of Ministers of Ukraine. Pro zatverdzhennia Poriadku provedennia perevirok derzhavnykh zakupivel Derzhavnoyu finansovoyu inspektsiieyu ta yii terytorialnymy orhanamy i vnesennia zmin do deiakykh aktiv Kabinetu Ministriv Ukrainy [On approval of the Procedure for conducting state procurement inspections by the State Financial Inspectorate and its local bodies and amending certain acts of the Cabinet of Ministers of Ukraine]. Resolution no. 631 of August 1, 2013. Retrieved from: http://zakon2.rada.gov.ua/laws/show/631-2013-\%D0\%BF (in Ukrainian)

Morhulets, O. B. (2012). Menedzhment u sferi posluh. navch. posib. [Management in the field of services: a teaching manual]. K.: Center for Educational Literature. (in Ukrainian)

Averianova, V. B. (Ed.). (2002). Vykonavcha vlada i administratyvne parvo [Executive power and administrative law]. K.: Publishing House "In-Yure". (in Ukrainian)

Averianova, V. B. (Ed.). (2003). Derzhavne upravlinnia: problemy administratyvno-pravovoyi teorii ta praktyky [Public administration: problems of the administrative-legal theory and practice]. K.: Fact. (in Ukrainian)

Voronova, L. K. (2006). Finansove pravo Ukrainy: pidruchnyk [Financial law of Ukraine: textbook]. K.: Pretsedent; Moia knyha. (in Ukrainian)

Nemchenko, V.V., Redko, O. Yu. (2012). Audyt. Osnovy derzhavnoho, nezalezhnoho profesiinoho ta vnutrishnoho audytu [Audit. Fundamentals of state, independent professional and internal audit]. K.: Center for Educational Literature. (in Ukrainian) 